\title{
Effects of Hydrogen-ion Concentration upon the Decomposition of Fish Muscle by Bacteria.
}

\author{
Masao KIMATA
}

\author{
(The Imperial Fisheries Institute, Tôkyô)
}

Effects of hydrogen-ion concentration upon the physiology of bacterin have been studied along two main paths, namely, on the growth rate of bacteria, and on the other physiological activities of them. The first has attracted much more attention of the bacteriologists than the second, but much is left to be desired in the technique. The second mostly concerns with the influence of initial $p H$ of the medium on the fermentation by lactic acid bacteria, Bact. coli, etc. Such investigations as carried out by MEYERHOF $^{(1)}$ into the oxidation of ammonia and nitrite, or by ITAxo ${ }^{(3)}$ into the decomposition of broth media in relation to the afore-mentioned conditions are not many. Still fewer are the papers which have dealt with the decomposition of the fish muscle under such conditions.

The present paper embodies my observations on the effects of $p H$ on the rate of the decomposition as well as the rate of growth of bacteria in the fish muscle suspensions.

\section{EXPERIMENT}

1. Cultural media:-One hundred c. c. of the fish muscle suspension were made by means of the previously reported method ${ }^{(3)}$, pipetted into sterilized fla $\mathbf{k}$ of $300 \mathrm{c}$. c. and added with an equal volume of sterilized distilled water and then added with a certain volume of sterilized $N \mathrm{NaOH}$ or $N \mathrm{HCl}$ and kept in a definite hydrogen ion concentration.

2. Organisms employed:-Pseudomonas fluorescens, Serratia marcescens, Achromobacter multistriatum, Proteus iulgaris, Staphylococcus aureus.

The first three water bacteria are known to be particularly concerned with fish muscle decomposition.

3. Procedure:-It is the same as the previously reported method ${ }^{(4)}$.

\section{RESULTS}

Various in hydrogen ion concentration may have markully diffcrent influences upon rates of growth of bacteria, and upon rates of production of

(1) Meyerhof, O.:-Arch. Physiol. 164, 165, 166, 19!6, 353, 229, 240.

(2) Itano, A :--Mass. Agr. Expt. Sta. Bull., Ii 7, 1916, 139.

(3) KrmatA, M :-Bull. Jap. Soc. Sei. Fish. 4, 1986, ‘94.

(4) Krmata, M :-Bull. Jap. Soc. Sci. Fish, 5, 1986, 77. 
formol titrating nitrogen and of volatile basic nitrogen from decomposed fish muscle by them.

1. Pseudomonas fuorescens:-The growth rate of bacteria remains unchanged at about $p H=6 \cdot 0 \sim 8 \cdot 0$, and velocity constant $(k)$ is about $5 \cdot 3$. But it decreases when hydrogen-ion concentration of the medium shifts a little to acid or alkaline side, the decrease bing more remarkable in the acid one than in alkaline.

The rate of formation of formol titrating nitrogen and volatile basic nitrogen from the fish muscle is the greatest at about $p H=6 \cdot 0$ (Fig. 1, B).

2. Serrativ marcescens:- The maximum growth rate is reached at about $p H=6.5$, the curve coming down more steeply in ac:d side than in alkaline one.

The rate of formation of the decomposition products of fi.h muscle is the greatest at about $p H=7 \cdot 0$ (Fig. $1, \mathrm{~A}$ ).

3. Achromobacter multistriatum:-The growth rate does not so much change within the range of $p H$ from 6.0 to $8 \cdot 0$, but its peak appears to lie at about $p H=65$.

The decomposition of fish muscle is nearly the same when $p H$ ranges $6 \cdot 5 \sim 8.5$, but it suddenly falls down in the acid reaction (Fig. 1, E).

4. Proteus vulgaris:-The growth rate is the greatest in about $p H=7 \cdot 0$ $\sim 8.5$.

The rate of the decomposition of the fish muscle appears to be the greatest at absut $p H=8 \cdot 0$ (Fig. 1, D).

5. Strphylococcus aureus:- It has a maximum in the growth rate at about $p H=7 \cdot 0$.

The rate of the decomposition seemis to reach its culmination at about $p H=6 \cdot 5$, although decomposing activity of the fish muscle by this bacteria in generally very weak (Fig. 1, C). 


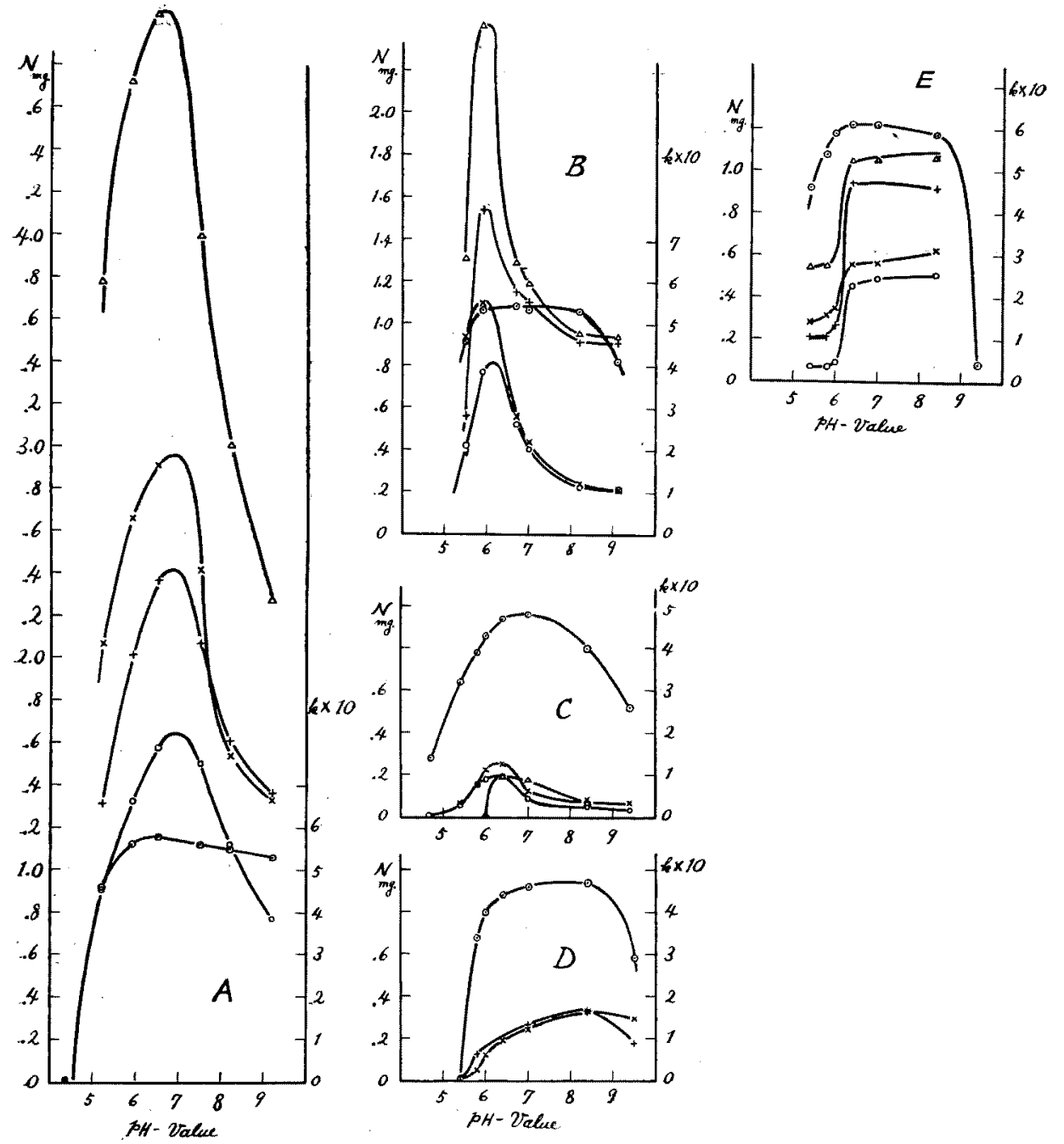

Fig. 1. The velocity constant (k) of the growth rates of bacteria, and the formol titrating nitrogen and the volatile basic nitrogen produced in relation to hydrogenion concent:ation.
A... Serratia marcescens
B.... Pseudomonas fluoresceris
C....Staphyloccccus aureus
D.... Protcus vulgaris
E....Achromobacter multistriatum
(.)...Velocity constant of the growth rate of bacteria.
O.... Formol titrating nitrogen produced in fivo days.
$x$.... Formol titrating nitrogen produced in seven days.
$+\ldots$ Volatile basic nitrogen produced in five days.
$\Delta$....Volatile basic nitrogen produced in seven day. 